\title{
Modeling of the adsorptive removal of arsenic(III) using plant biomass: a bioremedial approach
}

\author{
Palas Roy $^{1,2} \cdot$ Uttiya Dey $^{2} \cdot$ Soumya Chattoraj $^{2} \cdot$ Debasis Mukhopadhyay $^{3} \cdot$ \\ Naba Kumar Mondal ${ }^{2}$
}

Received: 21 August 2014/ Accepted: 4 September 2015/Published online: 19 September 2015

(C) The Author(s) 2015. This article is published with open access at Springerlink.com

\begin{abstract}
In the present work, the possibility of using a non-conventional finely ground $(250 \mu \mathrm{m})$ Azadirachta indica (neem) bark powder [AiBP] has been tested as a low-cost biosorbent for the removal of arsenic(III) from water. The removal of As(III) was studied by performing a series of biosorption experiments (batch and column). The biosorption behavior of As(III) for batch and column operations were examined in the concentration ranges of $50-500 \mu \mathrm{g} \mathrm{L}^{-1}$ and $500.0-2000.0 \mu \mathrm{g} \mathrm{L}^{-1}$, respectively. Under optimized batch conditions, the AiBP could remove up to $89.96 \%$ of $\mathrm{As}(\mathrm{III})$ in water system. The artificial neural network (ANN) model was developed from batch experimental data sets which provided reasonable predictive performance $\left(R^{2}=0.961 ; 0.954\right)$ of As(III) biosorption. In batch operation, the initial As(III) concentration
\end{abstract}

Naba Kumar Mondal

nkmenvbu@gmail.com

Palas Roy

palaschem@gmail.com

Uttiya Dey

uttiya.1988@gmail.com

Soumya Chattoraj

soumya_chattoraj@yahoo.co.in

Debasis Mukhopadhyay

mukhopadhyay.debasis@yahoo.co.in

1 Department of Chemistry, B.N. Mahavidyalaya (Itachuna), The University of Burdwan, Burdwan 713104, West Bengal, India

2 Environmental Chemistry Laboratory, Department of Environmental Science, The University of Burdwan, Burdwan, West Bengal 713104, India

3 Department of Economics, B.N. Mahavidyalaya (Itachuna), The University of Burdwan, Burdwan, West Bengal 713104, India had the most significant impact on the biosorption process. For column operation, central composite design (CCD) was applied to investigate the influence on the breakthrough time for optimization of As(III) biosorption process and evaluation of interacting effects of different operating variables. The optimized result of CCD revealed that the AiBP was an effective and economically feasible biosorbent with maximum breakthrough time of $653.9 \mathrm{~min}$, when the independent variables were retained at $2.0 \mathrm{~g}$ AiBP dose, $2000.0 \mu \mathrm{g} \mathrm{L}^{-1}$ initial As(III) concentrations, and $3.0 \mathrm{~mL} \mathrm{m^{-1 }}$ flow rate, at maximum desirability value of 0.969 .

Keywords Arsenic(III) removal - Low-cost adsorbent . Biosorption experiments · Artificial neural network model · Central composite design

$\begin{array}{ll}\text { Abbreviations } \\ \text { AiBP } & \text { Azadirachta indica bark powder } \\ \text { ANN } & \text { Artificial neural network } \\ \text { ANOVA } & \text { Analysis of variance } \\ \text { CCD } & \text { Central composite design } \\ \text { D-R } & \text { Dubinin-Radushkevich } \\ \text { RSM } & \text { Response surface methodology } \\ \text { Ag(-DDC) } & \text { Silver diethyl dithiocarbamate } \\ \text { SEM } & \text { Scanning electron microscopy } \\ \text { 2FI } & \text { Two factor interactions }\end{array}$

\section{Introduction}

Arsenic contamination in aqueous environment has become a global concern because of its serious environmental and health hazards (Mamun et al. 2009; Ranjan et al. 2009) in 
several developing regions. Arsenic can enter into streams, lakes, rivers, and groundwater (Mamun et al. 2009) through natural and human activities (Maiti et al. 2010). The existence of arsenic in groundwater, and eventually in drinking water can be dangerous because of the large quantity of water consumed by the human beings in long term (Mohan and Pittman 2007; Mamun et al. 2009).

High level of arsenic in drinking water sourced from groundwater has been reported in 21 countries (Mohan and Pittman 2007; Roy et al. 2014), especially Argentina, Bangladesh, India, Mexico, Mongolia, Thailand, and Taiwan, where a large proportion of groundwater is contaminated with arsenic at levels from 100 to over $2000 \mu \mathrm{g} \mathrm{L}^{-1}$ (Guo and Chen 2005).

In groundwater, arsenic is typically present in one of the two oxidation states: arsenite [As(III)] and arsenate $[\mathrm{As}(\mathrm{V})]$ of which $\mathrm{As}(\mathrm{III})$ is predominant and is generally more difficult to remove than $\mathrm{As}(\mathrm{V})$ (Kamala et al. 2005). Furthermore, As(III) is more mobile in groundwater and 25-60 times more toxic than As(V) (Ratna Kumar et al. 2004).

Due to the high toxic and delirious effects on human health (Guo and Chen 2005; Giri et al. 2011), the World Health Organization (WHO) has revised the safe limit for arsenic in drinking water from 50 to $10 \mu \mathrm{g} \mathrm{L}^{-1}$ (Maiti et al. 2010; Kamsonlian et al. 2012). This new regulation has posed a challenge for researchers to develop new technologies capable of selectively removing arsenic present at very low level, especially arsenic(III) [As(III)].

Development of effective technologies to remove arsenic from water drew great attention over the last two decades. Several physiochemical techniques, such as adsorption, ion exchange, lime softening, reverse osmosis, coagulation, and precipitation, have been applied to remove arsenic from aqueous system (Bhakat et al. 2007; Mohan and Pittman 2007; Ranjan et al. 2009; Giri et al. 2011; Kamsonlian et al. 2012). Among these removal technologies, adsorption technology is mainly used because it is very simple and cost effective (Bhattacharya et al. 2006; Ranjan et al. 2009; Kamsonlian et al. 2012). Besides, it is also popular due to availability of a wide range of adsorbents.

Among all types of conventional and non-conventional adsorbents, there has been an increasing tendency to use numerous inactive biological materials, or biosorbents, for the removal of arsenic from contaminated environment. However, only a limited number of biosorbents (without chemical modification) have been examined for their efficacy to remove arsenic from contaminated solutions (Baig et al. 2010; Sari and Tuzen 2010; Giri et al. 2011; Prasad et al. 2011; Sari et al. 2011; Kamsonlian et al. 2012; Pennesi et al. 2012; Wu et al. 2012; Giri et al. 2013; Nigam et al. 2013; Raj et al. 2013; Saqib et al. 2013).
The powdered form of brown-colored mature stem bark of the Azadirachta indica (neem) is an excellent example of such type of a non-conventional biosorbent. In recent years, this low-cost biosorbent has drawn much attention to the investigators due to its wide availability all over the world. The removal behavior of $\mathrm{Zn}$ (II) (Bhattacharya et al. 2006; Arshad et al. 2008; King et al. 2008; Naiya et al. 2009), Cd(II) (Tiwari et al. 1999; Naiya et al. 2009), Cr(VI) (Bhattacharya et al. 2008; Kumar and Phanikumar 2013) and dyes (Srivastava and Rupainwar 2010, 2011; Sadhukhan et al. 2014) from aqueous solutions on the A. indica bark powder (AiBP) had previously been investigated but not a single research has been reported on the removal of arsenic by AiBP.

In view of these attributes, it is of great interest to study the possibility for application of AiBP in the removal of arsenic from aqueous environment. With this goal in mind, the present study deals with a series of biosorption experiments (batch and column) to assess the potentiality of AiBP for removal of arsenic(III) from contaminated water. For sensitivity analysis and optimization abilities, the biosorption experiments have been statistically modeled using artificial neural network (ANN) and central composite design (CCD). The models were also applied to study the individuals as well as the combined effect of different variables influencing the biosorption process. As a whole a complete study for the economic, easy and eco-friendly solution of catastrophic arsenic pollution has been done, that can be implemented in the developing regions. Results obtained from this study are presented and discussed.

\section{Materials and methods}

\section{Reagents and apparatus}

Chemicals of analytical grade were procured from $\mathrm{M} / \mathrm{S}$, Merck India Ltd., and used in the study without further purification. All reagents and standards were prepared using double distilled water. Sodium arsenite $\left(\mathrm{NaAsO}_{2}\right)$ was used for the preparation of standard As(III) solution, and the required As(III) concentrations for experiments were prepared by serial dilution of standard solution on daily basis. All borosil glassware were cleaned by being soaked in $15 \% \mathrm{HNO}_{3}$ and rinsed with double distilled water. Different $\mathrm{pH}$ of $\mathrm{As}(\mathrm{III})$ solution were generated by the addition of $0.1 \mathrm{~N} \mathrm{H}_{2} \mathrm{SO}_{4}$ or $\mathrm{NaOH}$ solutions whenever necessary.

\section{Preparation of biosorbent}

The brown-colored neem (A. indica) bark used in the present study was collected from the university campus, 
Burdwan University, Burdwan. The collected A. indica bark was thoroughly washed with double distilled water to remove muddy materials and soaked in $0.1 \mathrm{~N} \mathrm{NaOH}$ to remove lignin-based color materials followed by $0.1 \mathrm{~N}$ $\mathrm{H}_{2} \mathrm{SO}_{4}$ (King et al. 2008; Naiya et al. 2009). The washed $A$. indica bark was dried in sun for 15 days. The resulting product was directly used as biosorbent. The dried bark was then cut into small pieces and ground to powder with kitchen grinder. For this experimental study, the powdered materials were sieved to obtain particle size of $250 \mu \mathrm{m}$ prior to use as biosorbent without any further treatment. The physiochemical characterization of the AiBP biosorbent has been reported elsewhere (Srivastava and Rupainwar 2011; Sadhukhan et al. 2014).

\section{Analytical determination of arsenic}

Estimation of As(III) was done spectrophotometrically by silver diethyl dithiocarbamate method (Gupta and Sankararamakrishnan 2010; Kamsonlian et al. 2012; Roy et al. 2013a) with minimum detectable amount of $1 \mu \mathrm{g}$ (Bhakat et al. 2007). This method is based on collection of arsine, $\mathrm{AsH}_{3}$ generated, through hydride formation of As(III), in silver diethyl dithiocarbamate $[\mathrm{Ag}(-\mathrm{DDC})]$ in pyridine solution and on subsequent reaction of $\mathrm{AsH}_{3}$ with $\mathrm{Ag}(-\mathrm{DDC})$ to form a colored As(-DDC) $)_{3}$ complex (Hautfenne 1980; Arbab-Zavar and Hashemi 2000).

$$
\mathrm{AsH}_{3}+6 \mathrm{Ag}(-\mathrm{DDC}) \rightarrow 6 \mathrm{Ag}+\mathrm{As}(-\mathrm{DDC})_{3}+3 \mathrm{H}(-\mathrm{DDC})
$$

Each sample was analyzed thrice and the results were found reproducible within $\pm 3 \%$ error limit. Calibration was carried out daily with a freshly prepared arsenic standard, before analysis. Experiment done with control biosorbent indicated no release of arsenic by the biosorbent. Blank experiments were also conducted to ensure that no adsorption was taking place on the walls of the apparatus used.

\section{Experimental setup}

In the batch operation, the effect of different parameters (i.e., $\mathrm{pH}$, contact time, initial concentration of As(III), dose of biosorbent, stirring rate, and temperature) on biosorption of As(III) was studied. The $100 \mathrm{~mL}$ solution of As(III) was taken in each Erlenmeyer flask separately. After $\mathrm{pH}$ adjustment, a known quantity of dried AiBP was added and the As(III) bearing suspensions was kept under magnetic stirring until the equilibrium was reached. After shaking, the suspension was allowed to settle down and filtered through a (Whatman No. 42 grade) filter paper. The filtrate was collected and subjected for arsenic estimation using Ag(-DDC) method. The arsenic concentrations before and after biosorption were recorded, and then the percent arsenic biosorption (removal) by the biosorbent was computed by using the following equation:

Percent biosorption (Removal) $=\left[\left(C_{i}-C_{e}\right) / C_{i}\right] \times 100$

where $C_{i}$ and $C_{e}$ are the initial and final concentration of As(III) in the solution.

The arsenic uptake loading capacity $\left(q_{e}=\mu \mathrm{g} \mathrm{g}^{-1}\right)$ of AiBP for different concentrations of As(III) at equilibrium was also determined as

$q e=\left(\frac{C i-C e}{M}\right) \times V$

where $V$ is the volume of solution (L) and $M$ is the mass of the biosorbent (g) used.

The experimental datasets, which were obtained from the batch operation, were used as inputs to the ANN model to provide the reasonable predictive performance of the biosorbent.

Fixed-bed column operation was conducted using borosil glass columns of $3-\mathrm{cm}$ internal diameter and $50-\mathrm{cm}$ length. The column was packed with different amounts of AiBP, in order to achieve different bed heights, between two supporting layers of $1-\mathrm{cm}$ of glass wool to prevent the floating of biosorbent.

The column studies were conducted to evaluate the effects of different variables [initial As(III) concentration, flow rate, and biosorbent dose] on the breakthrough time of As(III) biosorption by the biosorbent using CCD in response surface methodology (RSM). As(III) solution having the desired initial concentration was adjusted to the optimum batch $\mathrm{pH}$ for the maximum removal of arsenic, and pumped through the column bed at the desired flow rate in an up-flow mode. The flow rates were chosen to have sufficient amount of effluent per $30 \mathrm{~min}$ for the practical purpose of analyzing arsenic concentration. Operation of the column was stopped when the breakthrough time is achieved, the time at which the arsenic concentration in the effluent reached below $50 \mu \mathrm{g} \mathrm{L}^{-1}$. All of the experiments were carried out in triplicate at room temperature $\left(30^{\circ} \mathrm{C}\right)$ and the mean values were taken for analysis.

\section{Results and discussion}

\section{Batch operation}

\section{Effect of initial As(III) concentration}

The biosorption behavior of arsenic(III) was studied in the concentration range of $50-500 \mu \mathrm{g} \mathrm{L}^{-1}$ initially at $\mathrm{pH} 6.0$. 


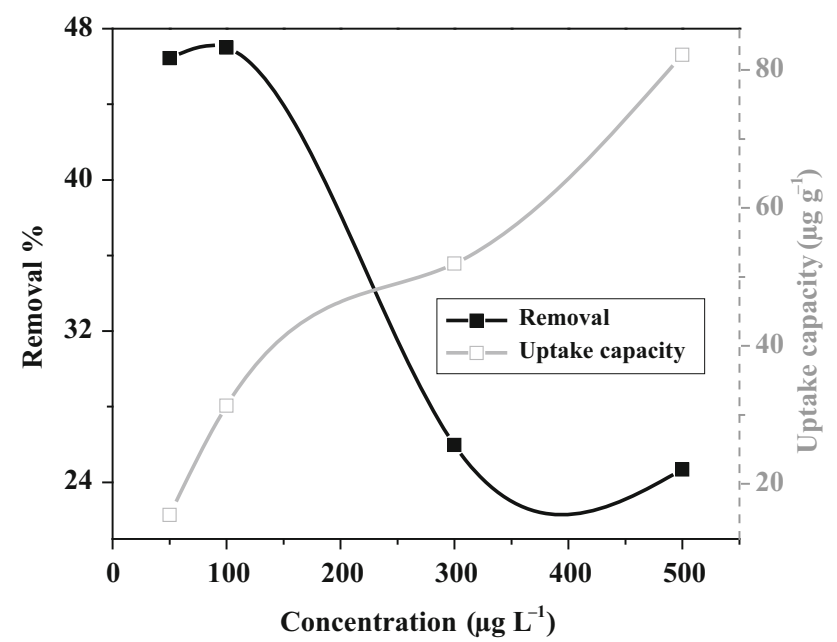

Fig. 1 Effect of initial arsenic(III) concentration on the biosorption of $\mathrm{As}(\mathrm{III})$ by AiBP. Dose $=0.15 \mathrm{~g}$, contact time $=20 \mathrm{~min}$, $\mathrm{pH}=6.0$, temperature $=30^{\circ} \mathrm{C}$, stirring rate $=500 \mathrm{rpm}$

In general, the removal percentage of As(III) on AiBP biosorbent was initially increased with the increasing initial concentration of arsenic reaching the optimum level of $46.99 \%$ at $100 \mu \mathrm{g} \mathrm{L}^{-1}$ arsenic concentration. Thereafter, the percentage of removal showed sharp decrease (Fig. 1). But the actual amount of arsenic adsorbed per unit mass of biosorbent was increased with increasing initial concentration in the test solution. This increase was probably due to decrease in resistance to the uptake of solute from solution with increasing initial arsenic concentration (Bhaumik et al. 2011; Suresh et al. 2012; Das et al. 2013).

\section{Effect of $p H$}

Figure 2 represents the percentage removal (or uptake capacity) as a function of the $\mathrm{pH}$ at optimum concentration $\left(100 \mu \mathrm{g} \mathrm{L}^{-1}\right)$ of As(III). The optimum removal of $46.99 \%$ $\left(31.32 \mu \mathrm{g} \mathrm{g}^{-1}\right)$ was obtained at the $\mathrm{pH}$ of 6.0. In the experimental $\mathrm{pH}$ range of 4.0-10.0, the predominant arsenite species are $\mathrm{H}_{3} \mathrm{AsO}_{3}$ and $\mathrm{H}_{2} \mathrm{AsO}_{3}{ }^{-}$(Ratna Kumar et al. 2004; Guo and Chen 2005; Kamala et al. 2005; Giri et al. 2011). At optimum $\mathrm{pH}$ of 6.0 , arsenite is probably absorbed through specific adsorption between the neutral species $\left(\mathrm{H}_{3} \mathrm{AsO}_{3}\right)$ and positively charged surface sites as the zeta potential: $\mathrm{pH}_{\mathrm{ZPC}}$ of $\mathrm{AiBP}=6.80$ (Srivastava and Rupainwar 2011). And the reduced trend of removal at higher $\mathrm{pH}$ might be attributed to an increase of negatively charged arsenite species $\left(\mathrm{H}_{2} \mathrm{AsO}_{3}{ }^{-}\right)$and negatively charge surface sites (Giri et al. 2011).

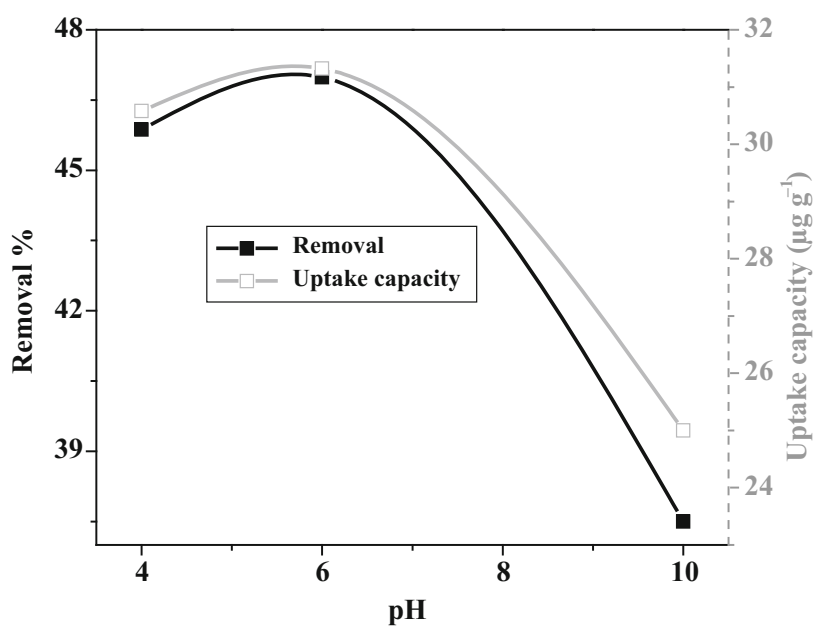

Fig. 2 Effect of $\mathrm{pH}$ on the biosorption of As(III) by AiBP. Initial arsenic(III) concentration $=100 \mu \mathrm{g} \mathrm{L}^{-1}$, dose $=0.15 \mathrm{~g}$, contact time $=20 \mathrm{~min}$, temperature $=30^{\circ} \mathrm{C}$, stirring rate $=500 \mathrm{rpm}$

\section{Effect of biosorbent dose}

In studying the influence of the dry weight of AiBP biomass on the removal efficiency at $\mathrm{pH} 6.0$ with initial As(III) concentration of $100 \mu \mathrm{g} \mathrm{L}^{-1}$, it was found that the removal efficiency of As(III) increased steadily (Fig. 3) with increasing biosorbent doses $(0.05-0.30 \mathrm{~g})$. No remarkable increment in the removal tendency was noted thereafter on further increasing the biosorbent dose. Increasing removal with biosorbent dose might be attributed to increase in biosorbent surface area with subsequent increment of more active binding sites (King et al. 2008; Kamsonlian et al. 2012; Das et al. 2014).

\section{Effect of contact time}

The effect of contact time on the biosorption of As(III) on AiBP biosorbent $(0.25 \mathrm{~g}$ dose $)$ was studied in the duration of 10-30 min at $\mathrm{pH} 6.0$ with initial As(III) concentration of $100 \mu \mathrm{g} \mathrm{L}^{-1}$. The percentage removal of arsenic showed a rapid and steady increase up to $20 \mathrm{~min}$, and thereafter, no significant increase was recorded. It seems possible that an equilibrium had set up in $20 \mathrm{~min}$ (Fig. 4). The fast biosorption rate at the initial stage may be explained by the abundant availability of active binding sites on the biosorbent surface (Srivastava and Rupainwar 2011; Das et al. 2013; Saqib et al. 2013). However, with a lapse of time, the remaining unsaturated sites cannot be occupied because of repulsive force between the solute (arsenic) on 


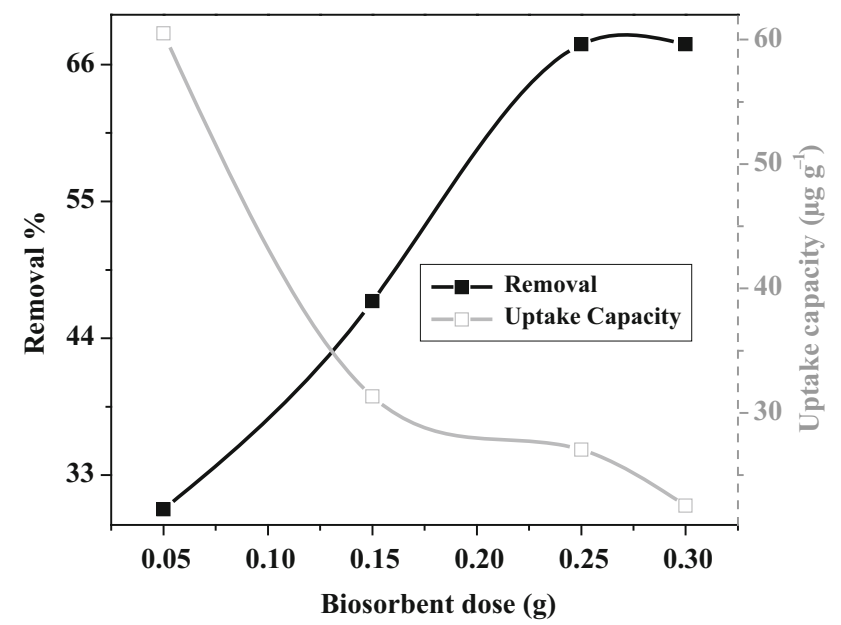

Fig. 3 Effect of biosorbent dose on the biosorption of As(III) by AiBP. Initial arsenic(III) concentration $=100 \mu \mathrm{g} \mathrm{\textrm {L } ^ { - 1 }}$, contact time $=20 \mathrm{~min}, \quad \mathrm{pH}=6.0, \quad$ temperature $=30{ }^{\circ} \mathrm{C}, \quad$ stirring rate $=500 \mathrm{rpm}$

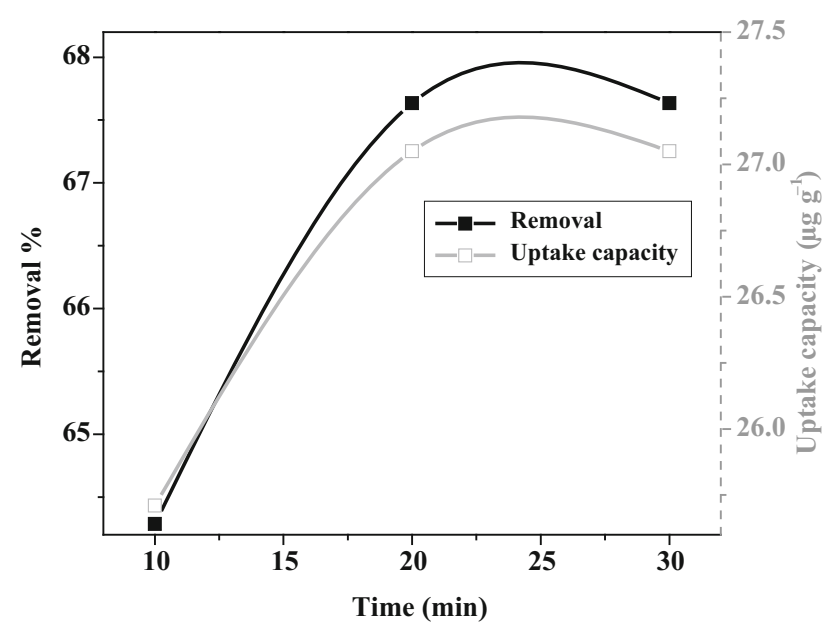

Fig. 4 Effect of contact time on the biosorption of As(III) by AiBP. Initial arsenic(III) concentration $=100 \mu \mathrm{g} \mathrm{L}^{-1}, \quad$ dose $=0.25 \mathrm{~g}$, $\mathrm{pH}=6.0$, temperature $=30^{\circ} \mathrm{C}$, stirring rate $=500 \mathrm{rpm}$

the solid and bulk phases (Rajesh Kannan et al. 2010; Roy et al. 2014).

\section{Effect of temperature}

The influence of temperature on the removal of As(III)by AiBP was measured at different temperatures ranging from 30 to $50{ }^{\circ} \mathrm{C}$. Figure 5 displays that the percent removal of As(III) was increased with temperature, from 67.63 to $78.24 \%$ when temperature was increased from 30 to $40{ }^{\circ} \mathrm{C}$. The removal probably reached equilibrium at $40{ }^{\circ} \mathrm{C}$ and thereafter slight decrease was noted. This explains that at very high temperature AiBP loses its biosorption power through denaturation (Rajesh Kannan et al. 2010; Kamsonlian et al. 2012).

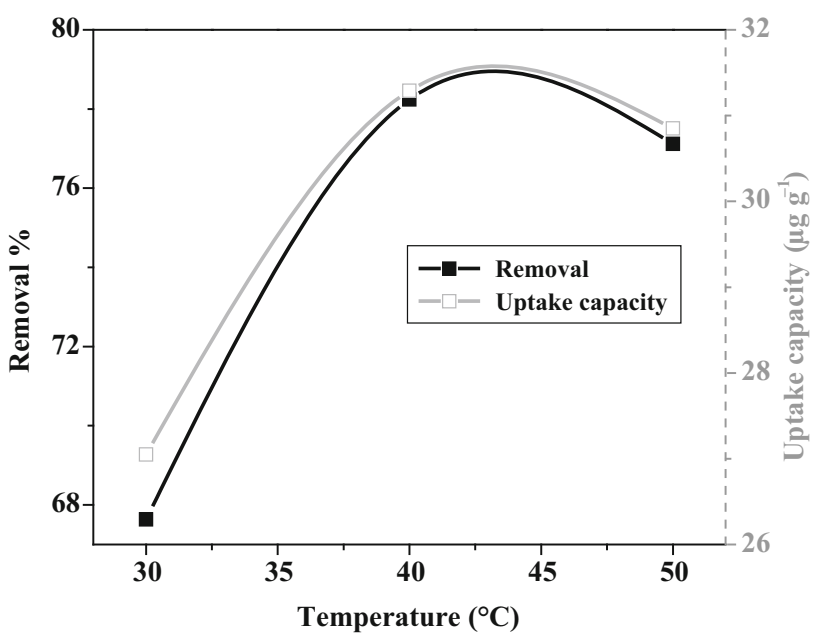

Fig. 5 Effect of temperature on the biosorption of As(III) by AiBP. Initial arsenic(III) concentration $=100 \mu \mathrm{g} \mathrm{L}^{-1}$, dose $=0.25 \mathrm{~g}$, contact time $=30 \mathrm{~min}, \mathrm{pH}=6.0$, stirring rate $=500 \mathrm{rpm}$

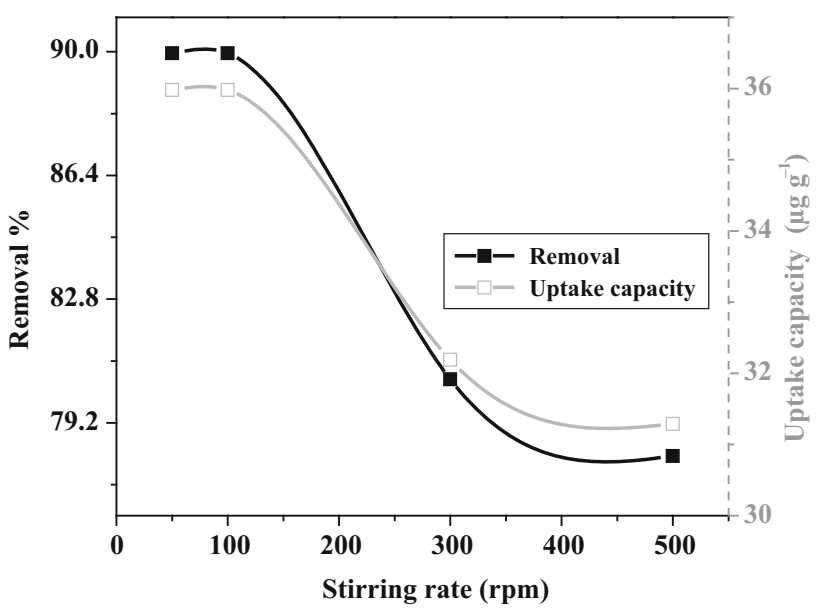

Fig. 6 Effect of stirring rate on the biosorption of As(III) by AiBP. Initial arsenic(III) concentration $=100 \mu \mathrm{g} \mathrm{L}^{-1}$, dose $=0.25 \mathrm{~g}$, contact time $=30 \mathrm{~min}, \mathrm{pH}=6.0$, temperature $=40{ }^{\circ} \mathrm{C}$

\section{Effect of stirring rate}

The effect of different stirring rate was studied with varying speeds from 50 to $500 \mathrm{rpm}$, and it appears that the percentage of As(III) removal was increased with decreasing stirring rate (Fig. 6). An increasing stirring rate did not give enough time for adsorbate and biosorbent surfaces to interact with each other and also resulted in detachment of loosely bounded adsorbates. However, maximum removal of $89.96 \%$ occurred as below as $100 \mathrm{rpm}$, while no increment was noted thereafter. This is because all the binding sites have been utilized and no binding sites were left for further biosorption (Kanwal et al. 2012; Roy et al. 2013a). 


\section{Artificial neural network (ANN) modeling}

In the last decade, ANN modeling has been successfully applied for estimating and predicting biosorption properties that are function of many variables and parameters. ANN is a statistical or computational model for processing of information based on the connectionist approach. This model has the ability to learn from existing data and adopt to map a set of input parameters into a set of output parameters, without knowing the intricate relationship among them. ANN can be trained to identify patterns and extract trends in imprecise and complicated non-linear data (Giri et al. 2011; Roy et al. 2013a, 2014). As biosorption is a complex non-linear process, neural network is found suitable for prediction of arsenic biosorption properties. Neural network toolbox of SPSS-17 mathematical software was used to predict the biosorption properties of AiBP under batch operation. Figure 7 shows the ANN model used in this study.

A total of 21 experimental datasets, which were obtained from batch operation, were used to develop a three-layer feed-forward neural network model by applying hyperbolic tangent function under the standardized method. Out of these 21 datasets, $66.7 \%$ were used to train the network, and remaining $33.3 \%$ were used for testing and validation of the ANN model. There were six neurons [viz., $\mathrm{pH}$, initial As(III) concentration, biosorbent dose, contact time, stirring rate and temperature] in the input layer whereas two neurons in the output layer (removal efficiency and uptake capacity). The 7-4-2 ANN (including bias neuron) model is found to be

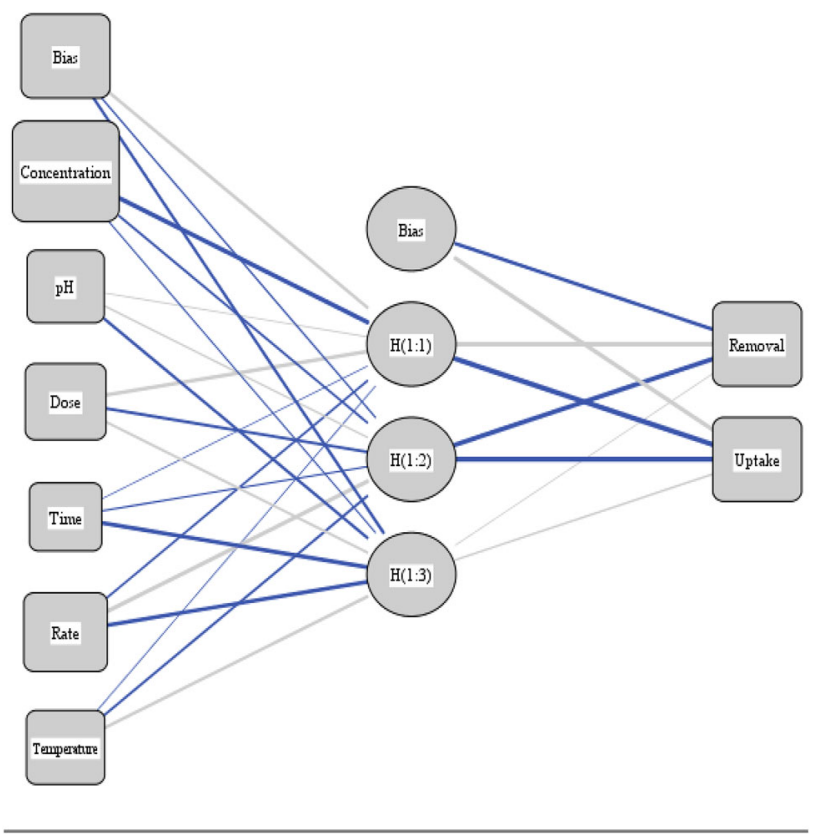

Hiddenl hyer activation functions: Hyperbolic tangent

Fig. 7 Neural network architecture of As(III) working satisfactorily with an average relative error of 0.352 and sum square error of 10.065 during testing phase, indicating that the model is able to predict the biosorption process with reasonable accuracy.

The performances of optimized ANN are shown in Figs. 8 and 9. In these Figures, experimental and ANNpredicted values are compared for both uptake capacity and removal of As(III), respectively. The values of $R^{2}$ (0.961; $0.954)$ very close to 1 for each case show an excellent agreement between the experimental and the ANN-predicted values.

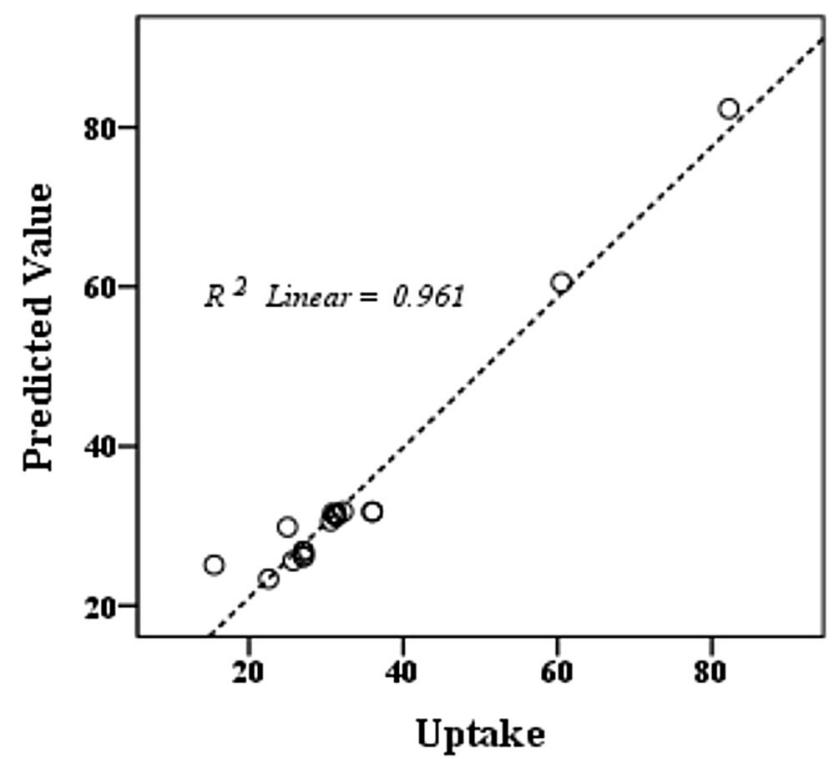

Fig. 8 Comparison of As(III) uptake for the experimental data and the simulation results in the training step of batch operation

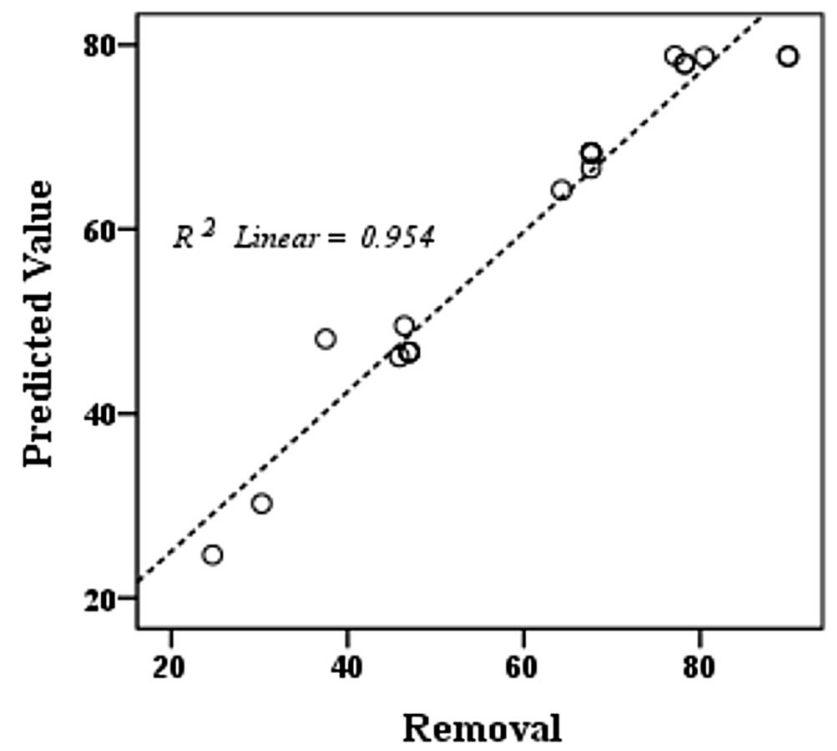

Fig. 9 Comparison of As(III) removal for the experimental data and the simulation results in the training step of batch operation 


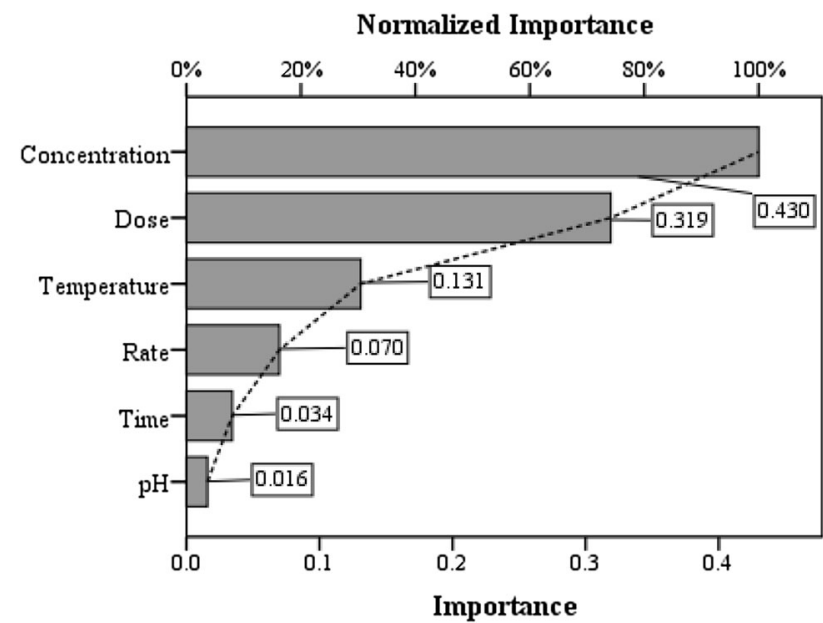

Fig. 10 Importance analysis of the various operating (input) parameters

The importance analysis for the developed network was also performed in order to determine the most significant parameter (Raj et al. 2013; Roy et al. 2014). It is reveled from the importance analysis (Fig. 10) that the initial concentration was the most significant parameter followed by biosorbent dose, temperature, stirring rate, contact time, and $\mathrm{pH}$. The influence percentages of these parameters on the output were $100.0,74.2,30.5,16.3,8.0$, and $3.7 \%$, respectively.

\section{Equilibrium isotherms and kinetics study}

An adsorption (biosorption) isotherm represents the equilibrium relationship between the adsorbate concentration in the liquid phase and that on the adsorbents surface at a given condition. A number of isotherms have been developed to describe equilibrium relationships. In the present study, the Langmuir, Freundlich, Temkin, and DubininRadushkevich (D-R) models were used to describe the equilibrium isotherms. The illustration of the equilibrium adsorption plots and the summarized isotherm models are shown in Fig. 11 and Table 1.
Fig. 11 Four adsorption equilibrium plots: Langmuir, Freundlich, Temkin, and D-R isotherm. Dose $=0.15 \mathrm{~g}$, contact time $=20 \mathrm{~min}$, $\mathrm{pH}=6.0$, temperature $=30{ }^{\circ} \mathrm{C}$, stirring rate $=500 \mathrm{rpm}$
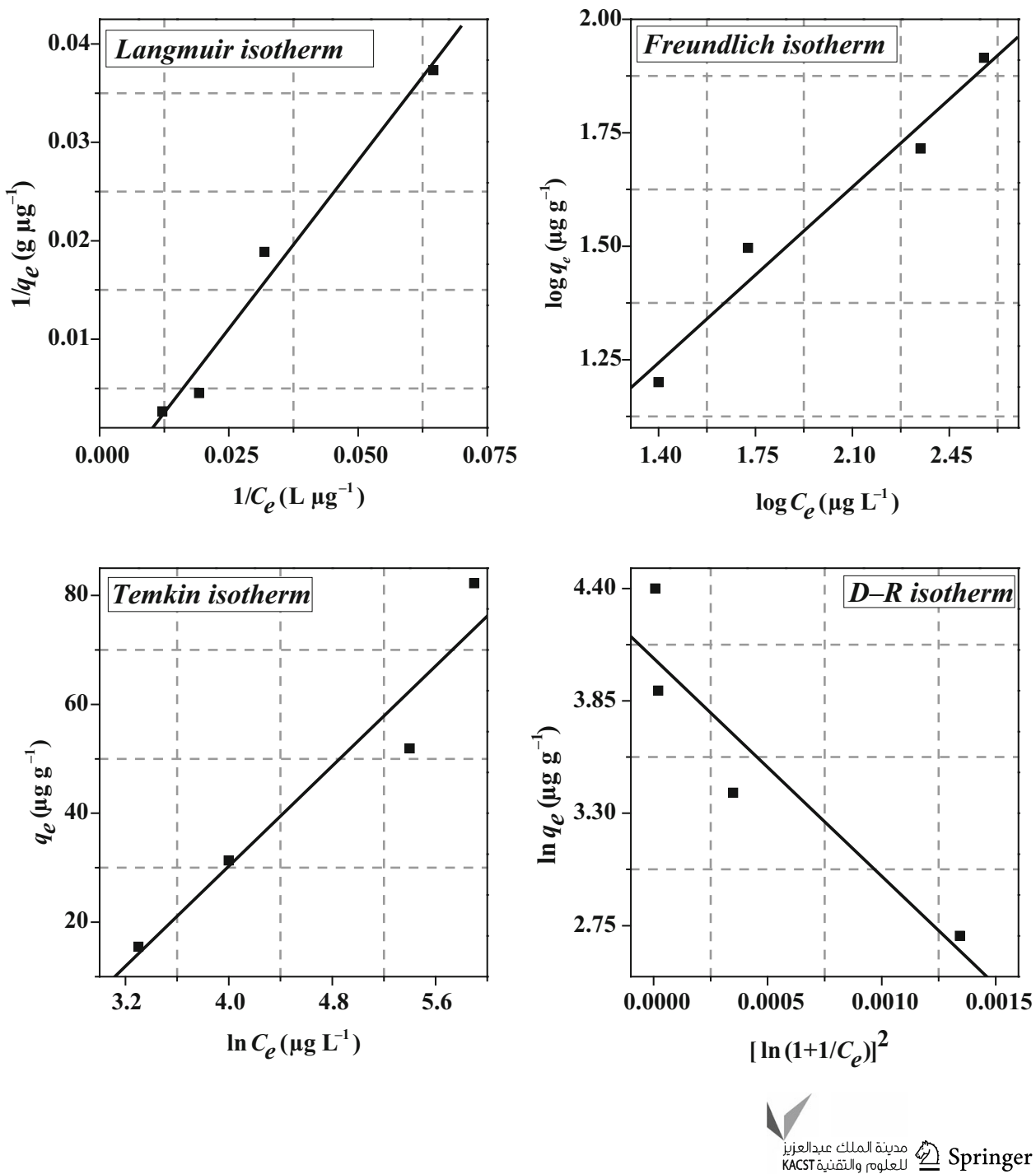
From Table 1, it is observed that the Langmuir isotherm showed good fit to the experimental equilibrium data than the Freundlich, Dubinin-Radishkevich, and Temkin isotherm equation for arsenic(III) biosorption according to the values of $R^{2}$. It is also seen from Table 1 that the Langmuir maximum biosorption capacity $q_{\max }\left(\mu \mathrm{g} \mathrm{g}^{-1}\right)$ is 166.7 and the equilibrium constant $K_{\mathrm{L}}\left(\mathrm{L} \mathrm{\mu g}^{-1}\right)$ is 0.009 . The separation factor $\left(R_{\mathrm{L}}\right)$ values are $0.695,0.532,0.275$, and 0.185 while initial As(III) concentrations are 50, 100, 300, and $500 \mu \mathrm{g} \mathrm{L}^{-1}$, respectively. All the $R_{\mathrm{L}}$ values were found to be less than one and greater than zero indicating the favorable biosorption of As(III) by AiBP. The Freundlich constant $K_{\mathrm{F}}$ indicates the adsorption capacity of the biosorbent and the value of $K_{\mathrm{F}}$ is $2.679 \mu \mathrm{g} \mathrm{g}^{-1}$. Furthermore, the value of ' $n$ ' at equilibrium is 1.757 . The value of $n$ lies in between 1 to 10 also represents a favorable biosorption. From Temkin constant, $b_{\mathrm{T}}$ related to adsorption binding energy for As(III) is found $111.4 \mathrm{~J} \mathrm{~mol}^{-1}$, clearly denying to follow the ion-exchange mechanism. In addition, D-R isotherm shows the value of the adsorption energy $(E)$ of $54.72 \mathrm{~J} \mathrm{~mol}^{-1}$. The estimated value of $E \quad\left(<8 \mathrm{~kJ} \mathrm{~mol}^{-1}\right)$ has been indicated toward the physisorption process (Baig et al. 2010; Das et al. 2014; Roy et al. 2014).

The pseudo-first-order and pseudo-second-order kinetic models were tested to investigate the rate of biosorption of As(III) by AiBP (Baig et al. 2010; Chattoraj et al. 2014).
The linearized form of adsorption kinetics and their constants are presented in Table 2 .

From the table, it is confirmed that the arsenic(III) biosorption followed the pseudo-second-order reaction. It is also clear from Table 2 that the pseudo-second-order kinetic model showed excellent linearity with high correlation coefficient $\left(R^{2}=0.999\right)$ at $100 \mu \mathrm{g} \mathrm{L}^{-1} \mathrm{As}(\mathrm{III})$ concentration in comparison to the first-order kinetic model. Furthermore, the calculated $q_{e}$ value also agrees with the experimental value $\left(31.3 \mu \mathrm{g} \mathrm{g}^{-1}\right)$ in the case of pseudo-second-order kinetic model.

\section{Thermodynamic parameters}

In order to describe thermodynamic properties of the biosorption of $\mathrm{As}(\mathrm{III})$ by $\mathrm{AiBP}$; enthalpy change $\left(\Delta H^{\circ}\right)$, Gibbs free energy change $\left(\Delta G^{\circ}\right)$, and entropy change $\left(\Delta S^{\circ}\right)$ were calculated by using equations as shown in Table 3.

From Table 3, it is clear that the biosorption process is thermodynamically feasible and spontaneous in nature as $\Delta G^{\circ}$ values are negative at all the temperature studied. The more negative value of $\Delta G^{\circ}$ with increasing in temperature suggests that higher temperature makes the biosorption easier. Again, the positive $\Delta H^{\circ}$ value implies the endothermic nature of the biosorption. The type of biosorption can be explained in terms of the magnitude of $\Delta H^{\circ}$. The enthalpy or the heat of adsorption ranging from

Table 1 Isotherm data for biosorption of As(III) by AiBP

\begin{tabular}{lllll}
\hline Adsorption isotherms & Equations & Parameters (unit) & Values & $R^{2}$ \\
\hline Langmuir isotherm & $\frac{1}{q_{e}}=\frac{1}{q_{\max } K_{\mathrm{L}} C_{e}}+\frac{1}{q_{\max }}$ & $q_{\max }\left(\mu \mathrm{g} \mathrm{g}^{-1}\right)$ & 166.7 & 0.977 \\
Freundlich isotherm & $\log q_{e}=\log K_{\mathrm{F}}+\frac{1}{n} \log C_{e}$ & $K_{\mathrm{L}}\left(\mathrm{L} \mathrm{gg}^{-1}\right)$ & 0.009 & 0.955 \\
& & $\left.K_{\mathrm{F}}(\mu \mathrm{g} \mathrm{g})^{-1}\right)$ & 2.679 & 1.757 \\
Temkin isotherm & $q_{e}=\frac{R T}{b_{\mathrm{T}}}\left(\ln A_{T}+\ln C_{e}\right)$ & $A_{\mathrm{T}}\left(\mathrm{L} \mathrm{\mu g}^{-1}\right)$ & 14.15 & 0.930 \\
& & $b_{\mathrm{T}}\left(\mathrm{J} \mathrm{mol}^{-1}\right)$ & 111.4 & 0.908 \\
D-R isotherm & $\ln q_{e}=\ln q_{\max }-\frac{1}{2 E^{2}} \times\left[R T \ln \left(1+\frac{1}{C_{e}}\right)\right]^{2}$ & $q_{\max }\left(\mu \mathrm{g} \mathrm{g}^{-1}\right)$ & 169.8 & \\
& & $E\left(\mathrm{~J} \mathrm{~mol}^{-1}\right)$ & 54.72 &
\end{tabular}

$q_{\max }$ is the maximum biosorption capacity; $K_{\mathrm{L}}, K_{\mathrm{F}}, A_{\mathrm{T}}$ and $b_{\mathrm{T}}$ are different biosorption constants; $n$ is the heterogeneity factor; $E$ is the mean free energy of biosorption per mole of the adsorbate; $T$ is the temperature $(\mathrm{K})$, and $R$ is the ideal gas constant $\left(8.3145 \mathrm{~J} \mathrm{~mol}^{-1} \mathrm{~K}^{-1}\right)$

Table 2 Kinetic parameters for biosorption of As(III) by AiBP

\begin{tabular}{|c|c|c|c|c|}
\hline Kinetic Models & Equations & Parameters (unit) & Values & $R^{2}$ \\
\hline Pseudo-first-order & $\ln q_{e}-q_{t}=\ln q_{e}-k_{1} t$ & $\begin{array}{l}q_{e}\left(\mu \mathrm{g} \mathrm{g}^{-1}\right) \\
k_{1}\left(\min ^{-1}\right)\end{array}$ & $\begin{array}{l}4.93 \\
0.546\end{array}$ & 0.875 \\
\hline Pseudo-second-order & $\frac{t}{q_{t}}=\frac{1}{k_{2} q_{e}^{2}}+\frac{t}{q_{e}}$ & 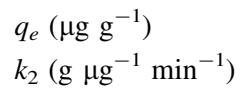 & $\begin{array}{l}33.2 \\
0.969\end{array}$ & 0.999 \\
\hline
\end{tabular}

$q_{\mathrm{t}}$ is the biosorption capacity at time $t ; k_{1}$ and $k_{2}$ are the first-order and second-order rate constant, respectively 
Table 3 Thermodynamic parameters for biosorption of As(III) by AiBP

\begin{tabular}{lll}
\hline Thermodynamic parameters & Equations & Values $\left(\mathrm{kJ} \mathrm{mol}^{-1}\right)$ \\
\hline Standard free energy & $\Delta G^{0}=-R T \ln K_{\mathrm{C}}$ & \\
$303 \mathrm{~K}$ & & -1.857 \\
$308 \mathrm{~K}$ & -2.538 \\
$313 \mathrm{~K}$ & -3.330 \\
$318 \mathrm{~K}$ & -3.297 \\
$323 \mathrm{~K}$ & -3.263 \\
Standard enthalpy change & $\ln K_{\mathrm{C}}=\frac{\Delta S^{0}}{R}-\frac{\Delta H^{0}}{R T}$ & 19.95 \\
Standard entropy change & & $72.9 \times 10^{-3}$ \\
\hline
\end{tabular}

$K_{\mathrm{C}}$ is the equilibrium constant, $T$ and $R$ are as defined in previous equation

2.1 to $20.9 \mathrm{~kJ} \mathrm{~mol}^{-1}$ corresponds to physical adsorption whereas ranging from 20.9 to $418 \mathrm{~kJ} \mathrm{~mol}^{-1}$ is regarded as chemical adsorption. Therefore, the $\Delta H^{\circ}$ value $\left(19.95 \mathrm{~kJ} \mathrm{~mol}^{-1}\right)$ confirms that the biosorption process of As(III) by AiBP occurred due to physisorptions. Furthermore, the positive $\Delta S^{\circ}$ value also corresponds to an increase in the degree of freedom of the adsorbed species during the biosorption process (Baig et al. 2010; Prasad et al. 2011; Das et al. 2014).

\section{Column operation}

\section{Central composite design (CCD)}

The RSM was applied to determine the optimized set of operational variables in the arsenic(III) biosorption process for the column study. The CCD in RSM was designed for a set of three independent variables, viz., initial As(III) concentration, flow rate, and biosorbent dose, to investigate their influence on the breakthrough time for continuous fixed-bed biosorption of As(III) by AiBP. The experimental range of the variables with their unit and notation used in CCD is given in Table 4.

The central composite design was developed by "Design-Expert" software. According to this design, a total of 20 experiments were performed in duplicate to the CCD matrix as per Table 5.

Table 4 Independent variables and their levels employed in the CCD

\begin{tabular}{lllrr}
\hline Variables & Units & Notations & \multicolumn{2}{c}{ Level of variables } \\
\cline { 3 - 5 } & & & Low & \multicolumn{1}{c}{ High } \\
\hline Initial concentration & $\mu \mathrm{g} \mathrm{L}^{-1}$ & $\mathrm{~A}$ & 500.0 & 2000.0 \\
Flow rate & $\mathrm{mL} \mathrm{min}^{-1}$ & $\mathrm{~B}$ & 3.0 & 7.0 \\
Biosorbent dose & $\mathrm{g}$ & $\mathrm{C}$ & 2.0 & 6.0 \\
\hline
\end{tabular}

\section{Evaluation of the fitting process model and ANOVA}

To detect and suggest a valid model, the actual responses were fitted with existing linear, two factor interactions (2FI), cubic and quadratic model by CCD. Based on suggestion, the quadratic model was selected to continue the progress (Table 6).

The selected quadratic model was validated by a few numbers of statistical evidences in the analysis of variance (ANOVA). The evidences were Fisher variation ratio ( $F$ value), probability value ( $p$ value), lack of fit, coefficient of determination $R$-squared $\left(R_{\mathrm{d}}^{2}\right)$, adjusted $R$-squared $\left(R_{\text {Adj }}^{2}\right)$, predicted $R$-squared $\left(R_{\text {Pred }}^{2}\right)$, and adequate precision. Adequate precision is a signal to-noise ratio, which compares the range of the predicted values at the design points to the average prediction error. The ratios greater than 4 indicate adequate model discrimination. $R_{\text {Adj }}^{2}$ and the $R_{\text {Pred }}^{2}$ are measurements of the amount of variation around the mean and new explained data, respectively. The $p$ value represents the degree of significance of each variable while $F$ value is a statistically valid measure of how well the factors describe the variation in the data about its mean (Abdollahi et al. 2012; Kumar and Phanikumar 2013; Chattoraj et al. 2014; Roy et al. 2014; Sadhukhan et al. 2014).

The selected model was validated by ANOVA which provided evidences such as high $F$ value (20202.14), very low $p$ value $(<0.0001)$, non-significant lack of fit, the high coefficient of $R$-squared (0.9999), adjusted $R$-squared (0.9999), predicted $R$-squared (0.9998), and the adequate precision (491.63). Moreover, Fig. 12 shows the actual values versus predicted values of the As(III) biosorption for column study, which indicates an excellent agreement between actual and predicted values. As observed, the validity (significance and adequacy) of the model was confirmed by the reasonable evidence.

The empirical relationships relating the breakthrough time to the tested independent variables have been expressed in terms of unit less regression coefficient by the quadratic model is given by the following equation:

Breakthrough time $(\mathrm{min})=+629.87-161.24 \mathrm{~A}$

$$
\begin{aligned}
& -201.96 \mathrm{~B}+230.59 \mathrm{C}-90.64 \mathrm{AB}-106.44 \mathrm{AC} \\
& -53.89 \mathrm{BC}+3.14 \mathrm{~A}^{2}+38.89 \mathrm{~B}^{2}+27.97 \mathrm{C}^{2}
\end{aligned}
$$

where A: initial concentration, B: flow rate, and C: biosorbent dose are in coded factors.

A regression analysis of the model equation (Table 7) shows that the main as well as the interaction effects of initial As(III) concentration, flow rate, and biosorbent dose were highly significant $(p<0.0001)$. Also, the square effect of flow rate and biosorbent dose was highly significant $(p<0.0001)$. 
Table 5 CCD for three used independent variables and the observed response (breakthrough time: $\min$ ) for As(III)

\begin{tabular}{lccllc}
\hline $\begin{array}{l}\text { Standard } \\
\text { order }\end{array}$ & $\begin{array}{l}\text { Run } \\
\text { order }\end{array}$ & $\begin{array}{l}\text { Factor 1 } \\
\text { A: initial } \\
\text { concentration } \\
\left(\mu \mathrm{g} \mathrm{L}^{-1}\right)\end{array}$ & $\begin{array}{l}\text { Factor } 2 \\
\text { B: flow } \\
\text { rate }\left(\mathrm{mL} \mathrm{min}^{-1}\right)\end{array}$ & $\begin{array}{l}\text { Factor 3 } \\
\text { C: biosorbent } \\
\text { dose }(\mathrm{g})\end{array}$ & $\begin{array}{l}\text { Response } \\
\text { Breakthrough } \\
\text { time (min) }\end{array}$ \\
\hline 4 & 1 & 500.0 & 3.0 & 2.0 & 581.0 \\
18 & 2 & 500.0 & 3.0 & 6.0 & 1366.3 \\
15 & 3 & 500.0 & 5.0 & 2.0 & 483.8 \\
2 & 4 & 500.0 & 5.0 & 6.0 & 1159.4 \\
13 & 5 & 500.0 & 7.0 & 2.0 & 466.2 \\
14 & 6 & 500.0 & 7.0 & 6.0 & 1032.2 \\
3 & 7 & 1250.0 & 3.0 & 2.0 & 615.8 \\
7 & 8 & 1250.0 & 3.0 & 6.0 & 1174.8 \\
11 & 9 & 1250.0 & 5.0 & 2.0 & 428.2 \\
10 & 10 & 1250.0 & 5.0 & 6.0 & 890.6 \\
5 & 11 & 1250.0 & 7.0 & 2.0 & 320.2 \\
20 & 12 & 1250.0 & 7.0 & 6.0 & 673.0 \\
1 & 13 & 2000.0 & 3.0 & 2.0 & 652.2 \\
8 & 14 & 2000.0 & 3.0 & 6.0 & 1013.0 \\
9 & 15 & 2000.0 & 5.0 & 2.0 & 374.2 \\
17 & 16 & 2000.0 & 5.0 & 6.0 & 623.4 \\
16 & 17 & 2000.0 & 7.0 & 2.0 & 175.8 \\
6 & 18 & 2000.0 & 7.0 & 4.0 & 315.4 \\
19 & 19 & 500.0 & 3.0 & 3.0 & 943.0 \\
\hline 12 & 20 & 500.0 & & & 9.0 \\
\hline
\end{tabular}

Table 6 Sequential model sum of squares

\begin{tabular}{|c|c|c|c|c|c|c|}
\hline Source & Sum of squares & $d f$ & Mean square & $F$ value & $p$ value, Prob $>F$ & \\
\hline Mean vs total & 10130195 & 1 & 10130195 & & & \\
\hline Linear vs mean & 1862252 & 3 & 620750.6 & 38.51 & $<0.0001$ & \\
\hline 2FI vs linear & 251448.7 & 3 & 83816.23 & 169.3 & $<0.0001$ & \\
\hline Quadratic vs 2FI & 6319.651 & 3 & 2106.55 & 180.7 & $<0.0001$ & Suggested \\
\hline Cubic vs quadratic & 58.73597 & 5 & 11.74719 & 1.015 & 0.4937 & Aliased \\
\hline Residual & 57.86444 & 5 & 11.57289 & & & \\
\hline Total & 12250332 & 20 & 612516.6 & & & \\
\hline
\end{tabular}

\section{Interaction effect of biosorption process variables}

Contour plots: In order to study the interaction among the different independent variables and their corresponding effect on the response, contour plots were drawn (Figs. 13, 14, 15). Contour plot is the projection of the response surface as a two-dimensional plane. This analysis gives a better understanding of the influence of variables and their interaction on the response.

The combined effect of initial As(III) concentration and flow rate on breakthrough time is shown in the contour plot of Fig. 13. The breakthrough time decreases with increase in both the initial As(III) concentration as well as the flow rate within the experimental range. Such behavior can be explained by the fact that all biosorbents have a limited number of active sites which become saturated at a certain concentration. With increasing inlet arsenic(III) concentration, the active sites on the biosorbent surface become more quickly saturated and hence the breakthrough time is decreased (Bhakat et al. 2007; Ranjan et al. 2009; Das et al. 2014). Also at higher flow rates, the residence time of the arsenic(III) solution in the column decreases. The insufficient residence time decreases the biosorption efficiency of As(III) on the biosorbent surface or diffusion into the pores of the biosorbent, leaving the column before equilibrium has reached with result in earlier breakthrough time (Gupta and Sankararamakrishnan 2010; Chowdhury et al. 2013; Saha et al. 2012; Roy et al. 2013a). 


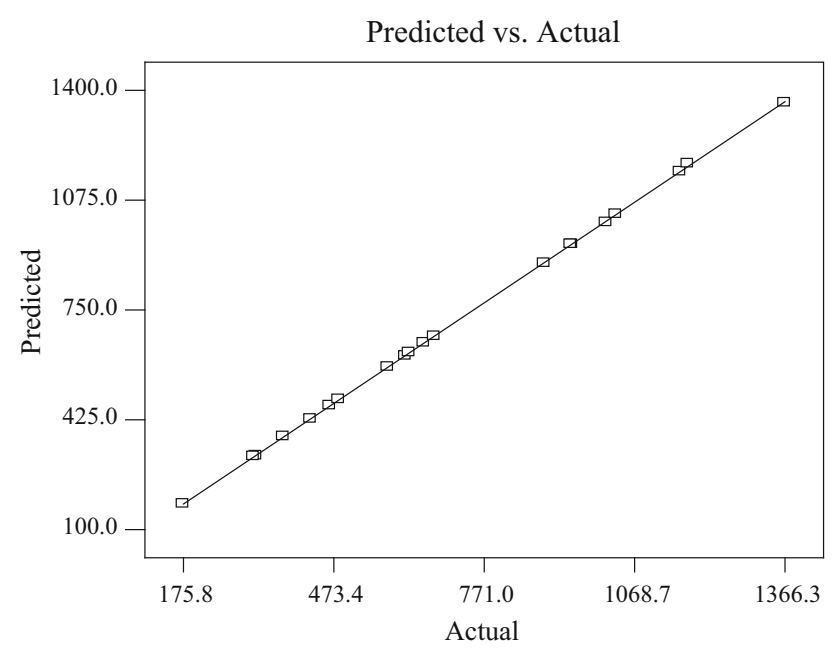

Fig. 12 Plot of actual response versus predicted response for column operation of As(III) biosorption by AiBP

Table 7 Regression Analysis using CCD

\begin{tabular}{lrllr}
\hline $\begin{array}{l}\text { Model } \\
\text { terms }\end{array}$ & $\begin{array}{l}\text { Coefficient } \\
\text { estimate }\end{array}$ & $\begin{array}{l}\text { Standard } \\
\text { error }\end{array}$ & $F$ value & $\begin{array}{l}p \text { value, } \\
\text { Prob }>F\end{array}$ \\
\hline A & -161.24 & 0.986 & 26757 & $<0.0001$ \\
B & -201.69 & 0.986 & 41866 & $<0.0001$ \\
$\mathrm{C}$ & 230.59 & 0.805 & 82086 & $<0.0001$ \\
$\mathrm{AB}$ & -90.64 & 1.207 & 5636 & $<0.0001$ \\
$\mathrm{AC}$ & -106.44 & 0.986 & 11660 & $<0.0001$ \\
$\mathrm{BC}$ & -53.89 & 0.986 & 2989 & $<0.0001$ \\
$\mathrm{~A}^{2}$ & 3.14 & 1.707 & 3.386 & 0.0956 \\
$\mathrm{~B}^{2}$ & 38.89 & 1.707 & 518.9 & $<0.0001$ \\
$\mathrm{C}^{2}$ & 27.97 & 3.244 & 74.31 & $<0.0001$ \\
\hline
\end{tabular}

Figure 14 depicts the interaction effect of initial As(III) concentration and biosorbent dose on the breakthrough time. Within the experimental range, the response function, i.e., the breakthrough time decreases with increasing initial As(III) concentration. On the contrary, the breakthrough time increases with increasing biosorbent dose. The observed trend can be attributed to the fact that increase in biosorbent doses in larger beds provides a greater number of active sites for As(III) with increase in the surface area of biosorbent (Bhakat et al. 2007; Ranjan et al. 2009; Roy et al. 2013a). The arsenic(III) has more time to contact with the biosorbent resulting in delayed breakthrough (Chowdhury et al. 2013; Saha et al. 2012; Roy et al. 2014).

The contour plot in Fig. 15 shows the combined effect of flow rate and biosorbent dose on the breakthrough time for continuous biosorption of As(III) by AiBP. The interactive effect of flow rate and biosorbent dose showed a significant impact on the breakthrough time. The breakthrough time decreases with increasing flow rate while it

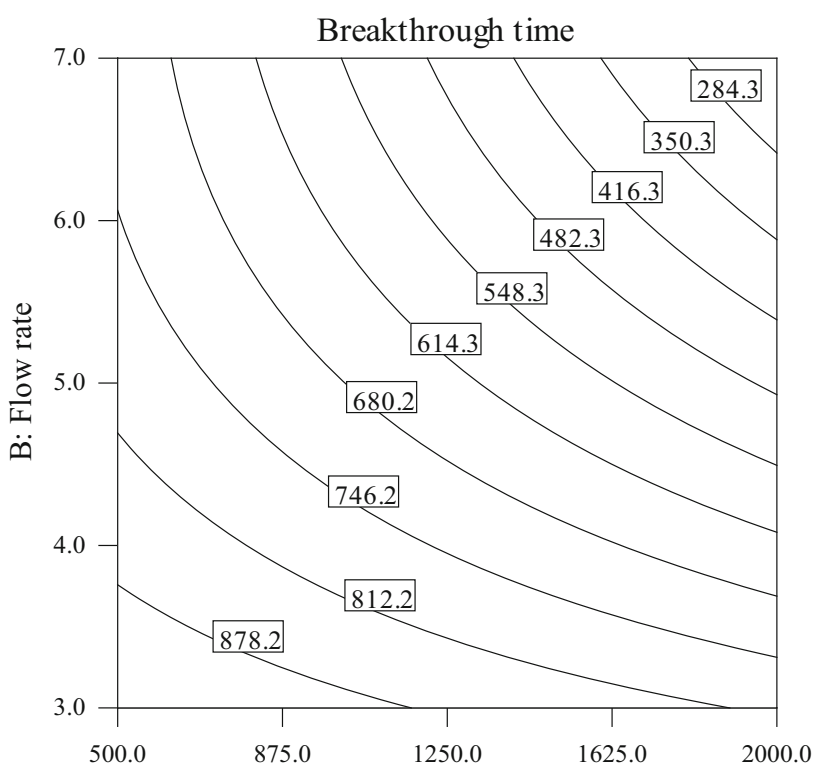

A: Initial concentration

Fig. 13 Contour plot showing the combined effect of initial arsenic(III) concentration and flow rate on the breakthrough time for column operation of As(III) biosorption by AiBP. Biosorbent dose of $4.0 \mathrm{~g}$

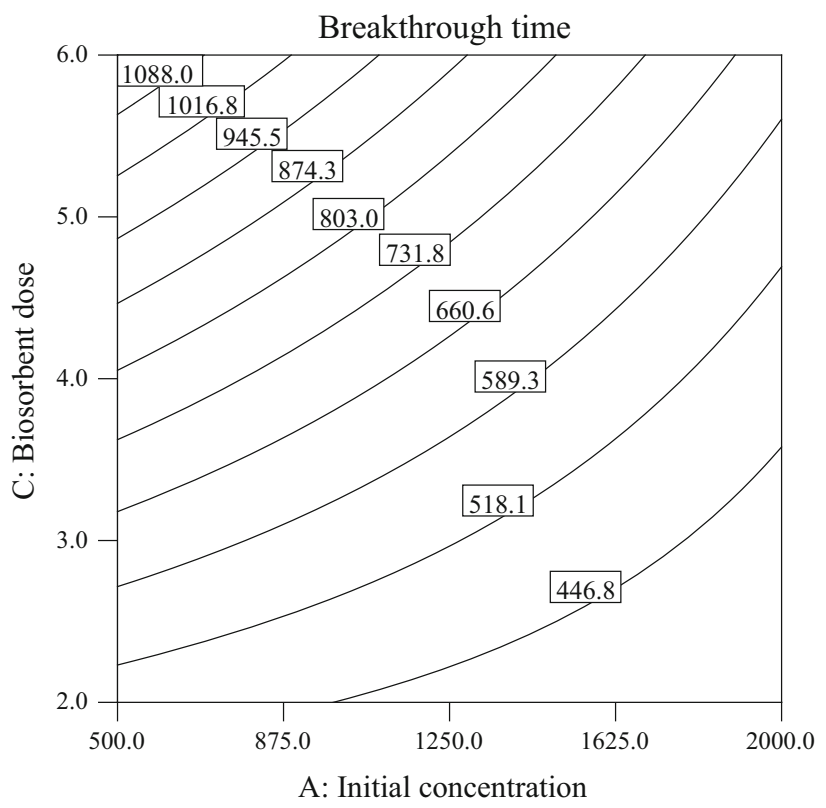

Fig. 14 Contour plot showing the combined effect of initial arsenic(III) concentration and biosorbent dose on the breakthrough time for column operation of As(III) biosorption by AiBP. Flow rate of $5.0 \mathrm{~mL} \mathrm{~min}^{-1}$

increases with increasing biosorbent dose. Such breakthrough pattern can be explained in terms of residence time of the arsenic ion in the column as well as the availability of active sites, as already mentioned. 


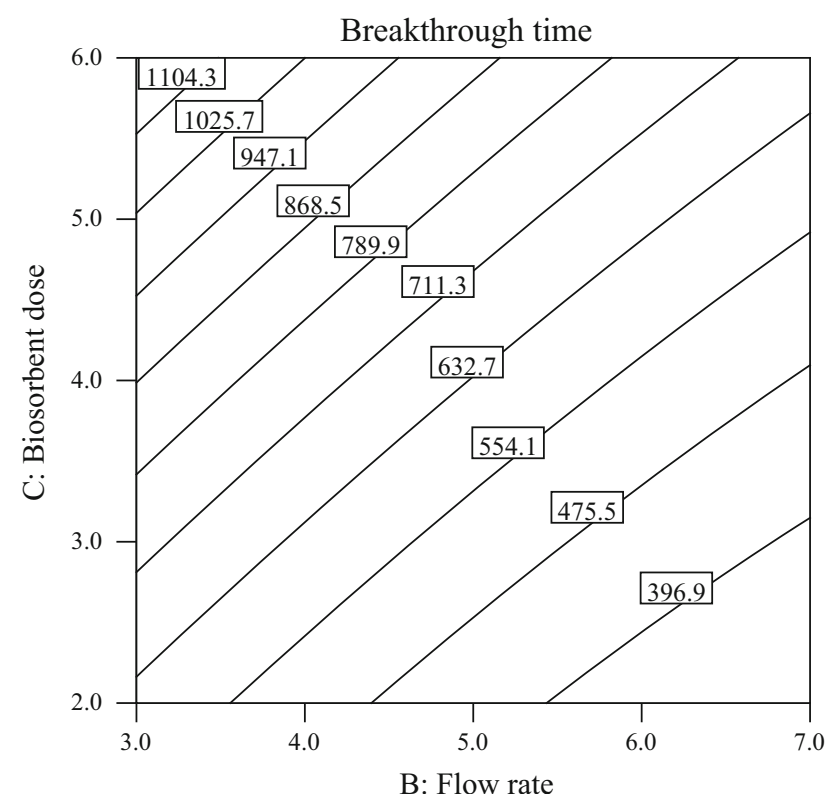

Fig. 15 Contour plot showing the combined effect of flow rate and biosorbent dose on the breakthrough time for column operation of As(III) biosorption by AiBP. Initial arsenic(III) concentration of $1250.0 \mu \mathrm{g} \mathrm{L}^{-1}$

Perturbation plot: The effects of initial As(III) concentration, flow rate, and biosorbent dose on the breakthrough time were evaluated. The individual effect of independent variables including initial As(III) concentration (A), flow rate (B), and biosorbent dose (C) was found by perturbation plot. A perturbation plot does not show the effect of interactions and it is like one factor-at-a-time experimentation. The perturbation plot as in Fig. 16 helps comparing the effect of all independent variables at a particular point in the design space. The response is plotted by changing only one factor over its range while holding the other factors constant. A steep slope or curvature in a factor shows that the response is sensitive to that factor (Kumar and Phanikumar 2013; Roy et al. 2014; Sadhukhan et al. 2014). A relatively flat line shows insensitivity to change in that particular factor. The present result revealed that breakthrough time is more sensitive to biosorbent dose followed by flow rate and initial concentration.

\section{Optimization using the desirability function}

The possible goals in the Design-Expert software's are to maximize, minimize, target, in range and set to an exact value (factors only). In numerical optimization, the desired goal was preferred for each variable and response from menu.

Figure 17 demonstrates the desirability values of optimization procedure in which the criterion was set as "minimum" for AiBP dose, "maximum" for initial As(III)

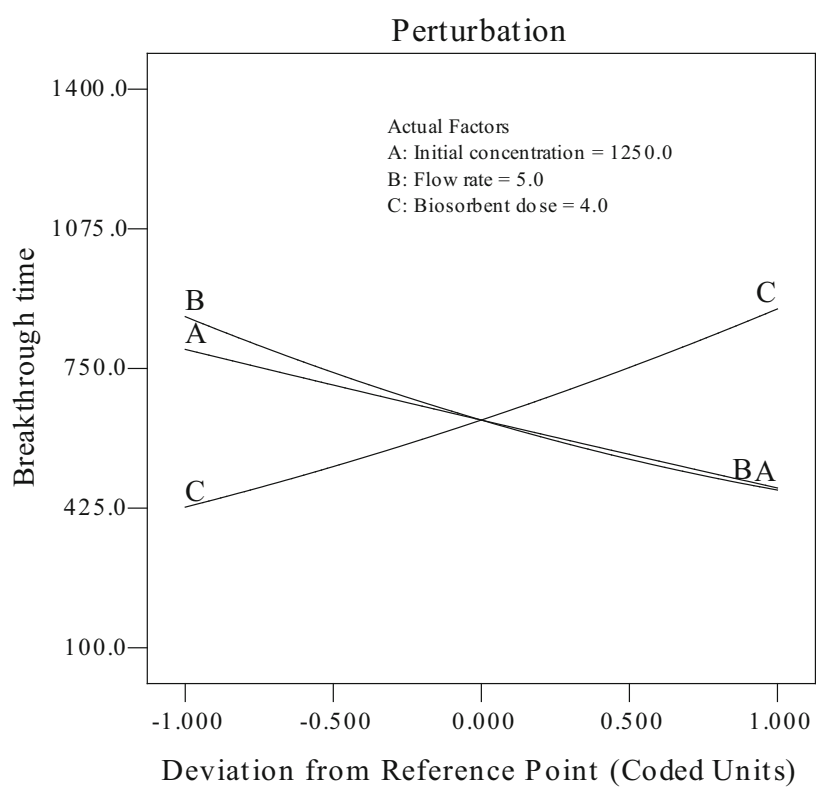

Fig. 16 Perturbation plot showing the effect of the tested variables on breakthrough time

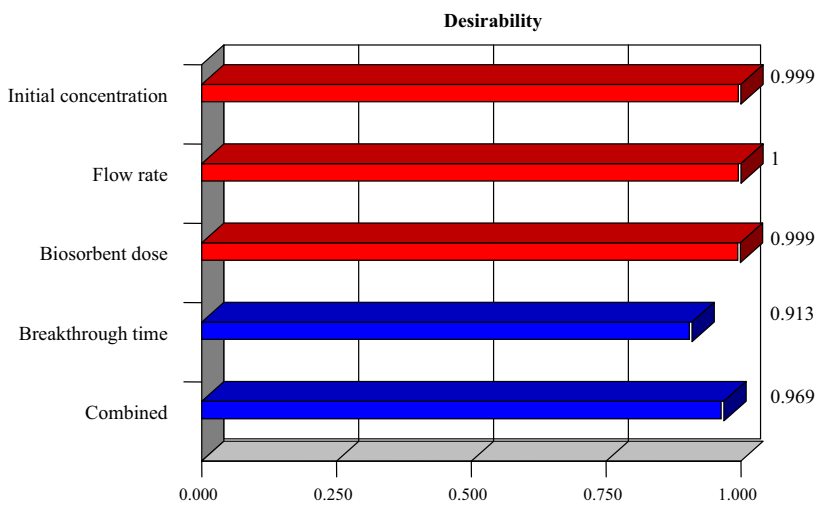

Fig. 17 Bar graph for optimization procedure

concentration, "in range" for flow rate and the goal was set as "maximum" to analyze economically viable optimal condition. The objective of this process was to find the maximum breakthrough time by utilizing less amount of biosorbent dose. In this, the desirability value ranges from 0.913 to 1 for individual variables and 0.969 for combination of all the variables.

By seeking from 100 starting points in the response surface changes, the best local maximum breakthrough time out of 34 solutions was found to be 653.9 min when the independent variables retained at $2.0 \mathrm{~g}$ AiBP dose, $2000.0 \mu \mathrm{g} \mathrm{L}^{-1}$ initial As(III) concentrations, and $3.0 \mathrm{~mL} \mathrm{m^{-1 }}$ flow rate at maximum desirability value of 0.969. The optimized result obtained from CCD coincides well with experimental value, suggesting that the AiBP may be an effective and economically feasible biosorbent for the removal of As(III) from water. 


\section{Scanning electron microscopy (SEM) analysis}

SEM analysis is a useful tool for the study of the surface morphology of the biosorbent. The SEM micrographs $(20 \mathrm{kV} ; 10 \mu \mathrm{m})$ at 1,000 magnifications for AiBP surface before and after As(III) biosorption at the optimization conditions of column operation are shown in Figs. 18 and 19 , respectively. Figure 18 clearly shows the presence of porous, rough, and irregular surface morphology of the

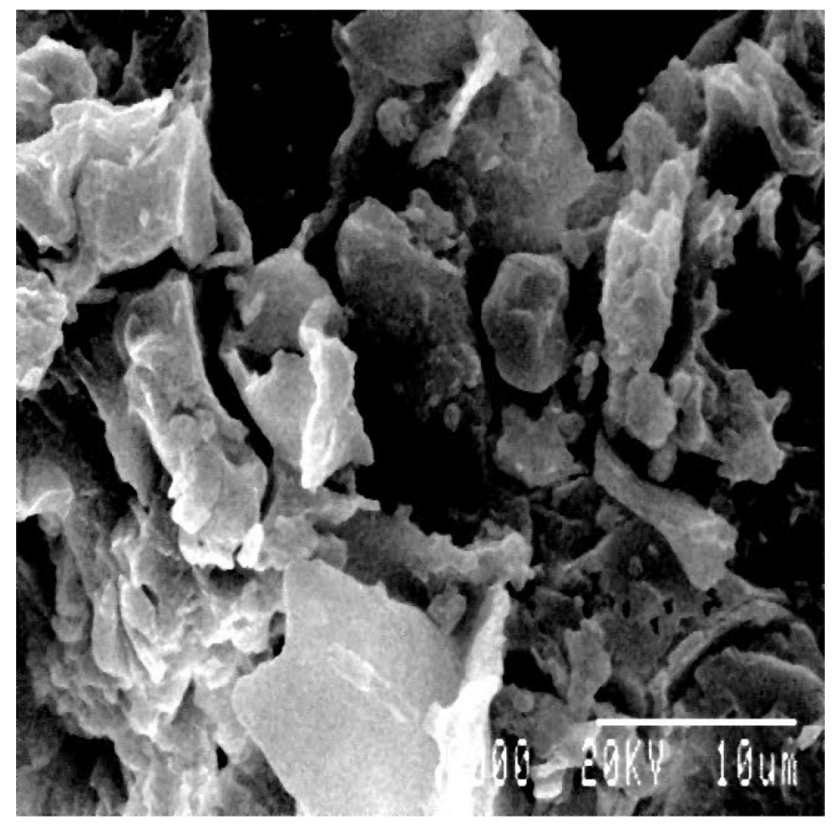

Fig. 18 SEM micrograph of AiBP before treatment of As(III)

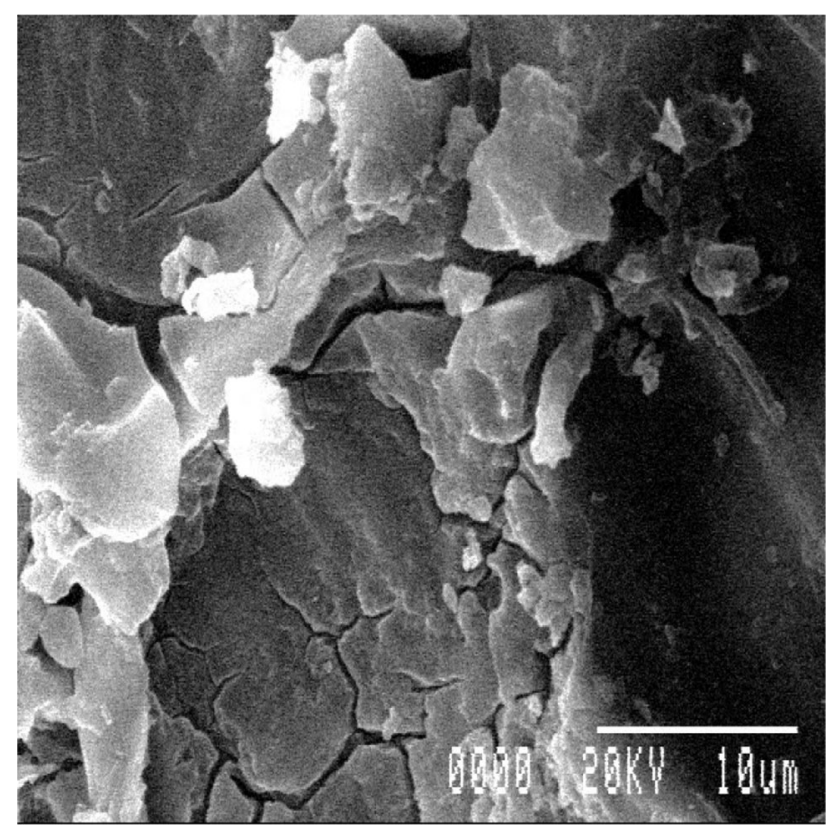

Fig. 19 SEM micrograph of AiBP after treatment of As(III) in column operation unloaded AiBP. The surface roughness of an unloaded biosorbent indicated the availability of a tremendous surface area of AiBP meant for high adsorption capacity in the biosorption process (Kamsonlian et al. 2012; Das et al. 2014; Roy et al. 2014). Contrary to this, after biosorption, the biosorbent surface seemed to have decreased porosity due to the heavy impregnation of As(III) onto the surface of the AiBP biomass (Fig. 19).

\section{Fixed-bed column performance using real contaminated groundwater (CGW)}

The proposed indigenous biosorbent AiBP was satisfactorily tested for the removal of arsenic from real CGW sample. Hundred ten natural CGW samples were collected from an arsenic polluted region of Purbasthali Block-II in the district of Burdwan, West Bengal, India (Roy et al. 2013b). Out of 110 tubewell water samples, the maximum concentration of inorganic arsenic (total) was $261 \mu \mathrm{g} \mathrm{L}^{-1}$ as recorded in our earlier study. Removal of arsenic from the CGW sample (total arsenic $=261 \mu \mathrm{g} \quad \mathrm{L}^{-1}$, As(III) $=112 \mu \mathrm{g} \mathrm{L}^{-1}$, and As(V) $=149 \mu \mathrm{g} \mathrm{L}{ }^{-1}$ ) by fixedbed column experiment was performed at optimal condition of $3.0 \mathrm{~mL} \mathrm{~min}{ }^{-1}$ flow rate and $2.0 \mathrm{~g}$ AiBP dose. After treating $15 \mathrm{~L}$ of $\mathrm{CGW}$ through the proposed column operation, the results on water quality before and after biosorption under study are shown in Table 8 . The results

Table 8 Physico-chemical parameters of water and removal of As(III) by AiBP

\begin{tabular}{lll}
\hline Parameters (Unit) & $\begin{array}{l}\text { Before } \\
\text { biosorption }\end{array}$ & $\begin{array}{l}\text { After } \\
\text { biosorption }\end{array}$ \\
\hline $\mathrm{pH}$ & 7.2 & 6.9 \\
Electrical conductivity $\left(\mu \mathrm{S} \mathrm{cm}^{-1}\right)$ & 3.8 & 3.4 \\
Total dissolve solid $\left(\mathrm{mg} \mathrm{L}^{-1}\right)$ & 536.8 & 455.7 \\
Carbonate $\left(\mathrm{mg} \mathrm{L}^{-1}\right)$ & 40.5 & 29.6 \\
Bicarbonate $\left(\mathrm{mg} \mathrm{L}^{-1}\right)$ & 220.3 & 176.3 \\
Calcium $\left(\mathrm{mg} \mathrm{L}^{-1}\right)$ & 126.2 & 87.6 \\
Magnesium $\left(\mathrm{mg} \mathrm{L}^{-1}\right)$ & 43.4 & 25.9 \\
Chloride $\left(\mathrm{mg} \mathrm{L}^{-1}\right)$ & 30.2 & 21.8 \\
Sodium $\left(\mathrm{mg} \mathrm{L}^{-1}\right)$ & 38.4 & 36.6 \\
Potassium $\left(\mathrm{mg} \mathrm{L}^{-1}\right)$ & 2.7 & 2.3 \\
Iron $\left.(\mathrm{mg} \mathrm{L})^{-1}\right)$ & 14.6 & 5.1 \\
Sulfate $\left(\mathrm{mg} \mathrm{L}^{-1}\right)$ & 3.8 & 2.4 \\
Phosphate $\left(\mathrm{mg} \mathrm{L}^{-1}\right)$ & 1.4 & 0.3 \\
Fluoride $\left(\mathrm{mg} \mathrm{L}^{-1}\right)$ & 0.5 & $\mathrm{BDL}$ \\
Antimony $\left(\mathrm{mg} \mathrm{L}^{-1}\right)$ & 0.3 & $\mathrm{BDL}$ \\
Total arsenic $\left(\mu \mathrm{g} \mathrm{L}^{-1}\right)$ & 261 & 33.2 \\
Arsenic $(\mathrm{III})\left(\mu \mathrm{g} \mathrm{L}^{-1}\right)$ & 112 & 12.3 \\
Arsenic $(\mathrm{V})\left(\mu \mathrm{g} \mathrm{L}^{-1}\right)$ & 149 & 20.9 \\
\hline BDL & &
\end{tabular}

$B D L$ below detection limit 
of column operation using real CGW sample, containing both $\mathrm{As}(\mathrm{III})$ and $\mathrm{As}(\mathrm{V})$ ions, showed that biosorbent is effective to remove both arsenic species from natural CGW. However, the concentration of arsenic (33.2, 12.3, and $20.9 \mu \mathrm{g} \mathrm{L}^{-1}$ ) in treated sample was higher than the safe level recommended by WHO. An additional biosorption step can be employed when single-stage biosorption is not enough to reduce the concentration of a pollutant to the recommended safe limit. Therefore, the present study recommends a two-stage biosorption by use of AiBP to reduce the arsenic concentration below $10 \mu \mathrm{g} \mathrm{L}^{-1}$.

\section{Conclusion}

AiBP was found to be efficacious in the removal of arsenic(III) from water. The effect of different process parameters (i.e., solution $\mathrm{pH}$, contact time, initial concentration of $\mathrm{As}(\mathrm{III})$, AiBP dose, stirring rate, and temperature) in batch operation were studied for the biosorption of As(III) on AiBP. ANN model was applied upon batch experimental values to archive the reasonable predictive performance of the biosorbent; additionally the importance analysis of ANN provided that the initial concentration was the most significant parameter for the batch operation. The model was also found to be working satisfactorily as evidenced with average relative error of 0.352 and sum square error of 10.065 during testing phase to predict the biosorption efficiency with reasonable accuracy. The study on equilibrium biosorption of batch operation revealed that Langmuir isotherm model gave the best fit to experimental data. The nature of biosorption of As(III) by AiBP was physisorption as inferred from the D-R isotherm model. The biosorption is pseudo-second-order, endothermic, and spontaneous. For column operation, CCD was applied to investigate the influence on the breakthrough time for optimization of As(III) biosorption process and evaluation of interacting effects of three different operating variables. A correlation coefficient $\left(R^{2}\right)$ value of 0.999 , model $F$ value of 20202.14 , and its low $p$ value $(<0.0001)$ along with higher adequate precision (491.63) indicated the fitness of the response surface quadratic model developed in the present study. The optimized result of $\mathrm{CCD}$ revealed that the AiBP was supposed to be an effective and economically feasible biosorbent for the removal of As(III) from the aqueous system. The effectiveness of the biosorbent is also critically examined by treating a contaminated groundwater sample collected form an arsenic affected area of Purbasthali Block-II, Burdwan, West Bengal, India. Overall, it is concluded that the data presented in this investigation can be further extrapolated for designing and establishing an efficient arsenic removal scheme while treating the groundwater that might have contaminated.
Acknowledgments The authors are thankful to the Department of Environmental Science, University of Burdwan, West Bengal, India for providing laboratory facilities for the work.

Open Access This article is distributed under the terms of the Creative Commons Attribution 4.0 International License (http:// creativecommons.org/licenses/by/4.0/), which permits unrestricted use, distribution, and reproduction in any medium, provided you give appropriate credit to the original author(s) and the source, provide a link to the Creative Commons license, and indicate if changes were made.

\section{References}

Abdollahi Y, Zakaria A, Matori KA, Shameli K, Jahangirian H, Rezayi M, Abdollahi T (2012) Interactions between photodegradation components. Chem Cent J 6:100. doi:10.1186/1752153X-6-100

Arbab-Zavar MH, Hashemi M (2000) Evaluation of electrochemical hydride generation for spectrophotometric determination of As(III) by silver diethyldithiocarbamate. Talanta 52:1007-1014

Arshad M, Zafar MN, Younis S, Nadeem R (2008) The use of neem biomass for the biosorption of zinc from aqueous solutions. J Hazard Mater 157:534-540

Baig JA, Kazi TG, Shah AQ, Kandhro GA, Afridi HI, Khan S, Kolachi NF (2010) Biosorption studies on powder of stem of Acacia nilotica: removal of arsenic from surface water. J Hazard Mater 178:941-948

Bhakat PB, Gupta AK, Ayoob S (2007) Feasibility analysis of As(III) removal in a continuous flow fixed bed system by modified calcined bauxite (MCB). J Hazard Mater B139:286-292

Bhattacharya AK, Mandal SN, Das SK (2006) Adsorption of Zn(II) from aqueous solution by using different adsorbents. Chem Eng J 123:43-51

Bhattacharya AK, Naiya TK, Mandal SN, Das SK (2008) Adsorption, kinetics and equilibrium studies on removal of $\mathrm{Cr}(\mathrm{VI})$ from aqueous solutions using different low-cost adsorbents. Chem Eng J 138:529-541

Bhaumik R, Mondal NK, Das B, Roy P, Pal KC (2011) Predicting iron adsorption capacity and thermodynamics onto calcareous soil from aqueous solution by linear regression and neural network modeling. Univers J Environ Res Technol 1:486-499

Chattoraj S, Mondal NK, Das B, Roy P, Sadhukhan B (2014) Biosorption of carbaryl from aqueous solution onto Pistia stratiotes biomass. Appl Water Sci 4:79-88

Chowdhury S, Chakraborty S, Saha PD (2013) Response surface optimization of a dynamic dye adsorption process: a case study of crystal violet adsorption onto $\mathrm{NaOH}$-modified rice husk. Environ Sci Pollut Res 20:1698-1705

Das B, Mondal NK, Roy P, Chattaraj S (2013) Equilibrium, kinetic and thermodynamic study on chromium(VI) removal from aqueous solution using Pistia stratiotes biomass. Chem Sci Trans 2:85-104

Das B, Mondal NK, Bhaumik R, Roy P (2014) Insight into adsorption equilibrium, kinetics and thermodynamics of lead onto alluvial soil. Int J Environ Sci Technol 11:1101-1114

Giri AK, Patel RK, Mahapatra SS (2011) Artificial neural network (ANN) approach for modelling of arsenic(III) biosorption from aqueous solution by living cells of Bacillus cereus biomass. Chem Eng J 178:15-25

Giri AK, Patel RK, Mahapatra SS, Mishra PC (2013) Biosorption of arsenic(III) from aqueous solution by living cells of Bacillus cereus. Environ Sci Pollut Res 20:1281-1291 
Guo X, Chen F (2005) Removal of arsenic by bead cellulose loaded with iron oxyhydroxide from groundwater. Environ Sci Technol 39:6808-6818

Gupta A, Sankararamakrishnan N (2010) Column studies on the evaluation of novel spacer granules for the removal of arsenite and arsenate from contaminated water. Bioresour Technol 101:2173-2179

Hautfenne A (1980) Standard methods for the analysis of oils, fats and derivatives, 6th Edn. 1st Supplement: Part 2, IUPAC, Great Britain

Kamala CT, Chu KH, Chary NS, Pandey PK, Ramesh SL, Sastry AR, Sekhar KC (2005) Removal of arsenic(III) from aqueous solutions using fresh and immobilized plant biomass. Water Res 39:2815-2826

Kamsonlian S, Suresh S, Majumder CB, Chand S (2012) Biosorption of $\mathrm{As}(\mathrm{III})$ from contaminated water onto low cost palm bark biomass. Int J Curr Eng Technol 2:153-158

Kanwal F, Rehman R, Mahmud T, Anwar J, Ilyas R (2012) Isothermal and thermodynamical modeling of chromium(III) adsorption by composites of polyaniline with rice husk and saw dust. J Chil Chem Soc 57:1058-1063

King P, Anuradha K, Lahari SB, Prasanna Kumar Y, Prasad VS (2008) Biosorption of zinc from aqueous solution using Azadirachta indica bark: equilibrium and kinetic studies. J Hazard Mater 152:324-329

Kumar MPS, Phanikumar BR (2013) Response surface modelling of $\mathrm{Cr}^{6+}$ adsorption from aqueous solution by neem bark powder: box-behnken experimental approach. Environ Sci Pollut Res 20:1327-1343

Maiti A, Basu JK, De S (2010) Development of a treated laterite for arsenic adsorption: effects of treatment parameters. Ind Eng Chem Res 49:4873-4886

Mamun AA, Maan FR, Zahiarh AK, Yehya MA, Mohammed ARS, Alam MZ, Muyibi SA, Faris IA, Azin I (2009) Optimisation of arsenic adsorption from water by carbon nanofibers grown on powdered activated carbon impregnated with nickel. J Appl Sci 9:3180-3183

Mohan D, Pittman CU Jr (2007) Arsenic removal from water/ wastewater using adsorbents-a critical review. J Hazard Mater 142:1-53

Naiya TK, Chowdhury P, Bhattacharya AK, Das SK (2009) Saw dust and neem bark as low-cost natural biosorbent for adsorptive removal of $\mathrm{Zn}$ (II) and $\mathrm{Cd}(\mathrm{II})$ ions from aqueous solutions. Chem Eng J 148:68-79

Nigam S, Gopal K, Vankar PS (2013) Biosorption of arsenic in drinking water by submerged plant: Hydrilla verticilata. Environ Sci Pollut Res 20:4000-4008

Pennesi C, Veglio F, Totti C, Romagnoli T, Beolchini F (2012) Nonliving biomass of marine macrophytes as arsenic $(\mathrm{V})$ biosorbents. J Appl Phycol 24:1495-1502

Prasad KS, Srivastava P, Subramanian V, Paul J (2011) Biosorption of As(III) ion on Rhodococcus sp. WB-12: biomass characterization and kinetic studies. Sep Sci Technol 46:2517-2525

Raj KR, Kardam A, Arora JK, Srivastava S (2013) An application of ANN modeling on the biosorption of arsenic. Waste Biomass Valorization 4:401-407
Rajesh Kannan R, Rajasimman M, Rajamohan N, Sivaprakash B (2010) Equilibrium and kinetic studies on sorption of malachite green using Hydrilla verticillata biomass. Int J Environ Res 4:817-824

Ranjan D, Talat M, Hasan SH (2009) Rice polish: an alternative to conventional adsorbents for treating arsenic bearing water by upflow column method. Ind Eng Chem Res 48:10180-10185

Ratna Kumar P, Chaudhari S, Khilar KC, Mahajan SP (2004) Removal of arsenic from water by electrocoagulation. Chemosphere 55:1245-1252

Roy P, Mondal NK, Bhattacharya S, Das B, Das K (2013a) Removal of arsenic(III) and arsenic(V) on chemically modified low-cost adsorbent: batch and column operation. Appl Water Sci 3:293-309

Roy P, Mondal NK, Das B, Das K (2013b) Arsenic contamination in groundwater: a statistical modeling. J Urban Environ Eng 7:24-29

Roy P, Mondal NK, Das K (2014) Modeling of the adsorptive removal of arsenic: a statistical approach. J Environ Chem Eng 2:585-597

Sadhukhan B, Mondal NK, Chattoraj S (2014) Biosorptive removal of cationic dye from aqueous system: a response surface methodological approach. Clean Techn Environ Policy 16:1015-1025

Saha PD, Chakraborty S, Chowdhury S (2012) Batch and continuous (fixed-bed column) biosorption of crystal violet by Artocarpus heterophyllus (jackfruit) leaf powder. Colloids Surf B Biointerfaces 92:262-270

Saqib ANS, Waseem A, Khan AF, Mahmood Q, Khan A, Habib A, Khan AR (2013) Arsenic bioremediation by low cost materials derived from blue pine (Pinus wallichiana) and walnut (Juglans regia). Ecol Eng 51:88-94

Sari A, Tuzen M (2010) Biosorption of As(III) and As(V) from aqueous solution by lichen (Xanthoria parietina) biomass. Sep Sci Technol 45:463-471

Sari A, Uluozlu OD, Tuzen M (2011) Equilibrium, thermodynamic and kinetic investigations on biosorption of arsenic from aqueous solution by algae (Maugeotia genuflexa) biomass. Chem Eng J 167:155-161

Srivastava R, Rupainwar DC (2010) Liquid phase adsorption of indigo carmine and methylene blue on neem bark. Desalin Water Treat 24:74-84

Srivastava R, Rupainwar DC (2011) A comparative evaluation for adsorption of dye on neem bark and mango bark powder. Indian J Chem Technol 18:67-75

Suresh S, Srivastava VC, Mishra IM (2012) Adsorptive removal of aniline by granular activated carbon from aqueous solutions with catechol and resorcinol. Environ Technol 33:773-781

Tiwari D, Mishra SP, Mishra M, Dubey RS (1999) Biosorptive behaviour of mango (Mangifera indica) and neem (Azadirachta indica) bark for $\mathrm{Hg}^{2+}, \mathrm{Cr}^{3+}$ and $\mathrm{Cd}^{2+}$ toxic ions from aqueous solutions: a radiotracer study. Appl Radiat Isot 50:631-642

Wu Y, Wen Y, Zhou J, Dai Q, Wu Y (2012) The characteristics of waste Saccharomyces cerevisiae biosorption of arsenic(III). Environ Sci Pollut Res 19:3371-3379 